\title{
Preliminary estimation of the export of omega-3 polyunsaturated fatty acids from aquatic to terrestrial ecosystems in biomes via emergent insects
}

\author{
Michail I. Gladyshev a,b, Elena E. Gladysheva, ${ }^{a,}$, Nadezhda N. Sushchik ${ }^{a, b}$
}

${ }^{a}$ Siberian Federal University, Svobodny av. 79, Krasnoyarsk, 660041, Russia

b Institute of Biophysics of Federal Research Center "Krasnoyarsk Science Center" of Siberian Branch of Russian Academy of Sciences, Akademgorodok, Krasnoyarsk, 660036, Russia

* Corresponding author.

E-mail address:elenagladysheva@yahoo.com (E. E. Gladysheva).

\begin{abstract}
For future estimating of potential limitation of some terrestrial consumers by food quality in global scale, the water-land fluxes of essential polyunsaturated fatty acids (PUFA), eicosapentaenoic acid (20:5n-3, EPA) and docosahexaenoic acid (22:6n-3, DHA), with the biomass of emergent aquatic insects in several biomes were estimated. The water /land area ratios for each biome were calculated by dividing the water area of each biome by its terrestrial area. Data on insect emergence from water bodies ( $\mathrm{g}$ of dry mass $\mathrm{m}^{-2}$ year $^{-1}$ ), were generalized and averaged for each biome.From available data, EPA and DHA contents ( $\mathrm{mg} \mathrm{g}^{-1}$ dry mass), in the biomass of emergent aquatic insects were calculated first so that annual fluxes of PUFA to land area via aquatic insect emergence could be estimated for each biome. A high variability of PUFA fluxes occurred between the biomes, ranging from 0.04 to $4.39 \mathrm{mg} \cdot \mathrm{m}^{-2} \cdot \mathrm{year}^{-1}$. In this study, the aquatic PUFA supply to land area appeared to be significantly lower than that of a previous global average estimate. This finding indicates that a putative limitation of some terrestrial consumers by food quality, namely by the supply of aquatic PUFA, may be more severe than was previously determined.
\end{abstract}

Key words: eicosapentaenoic acid, docosahexaenoic acid, aquatic-terrestrial subsidies, food quality, water/land area ratio

\section{Introduction}

Matter and energy exchange between terrestrial and aquatic ecosystems, often designated 'reciprocal subsidies', has appeared as one of the hot topics in ecology in recent decades (Baxter 
et al., 2005; Ballinger and Lake, 2006; Gratton and Vander Zanden, 2009; Richardson et al., 2010; Bartels et al., 2012; Schulz et al., 2015; Schindler and Smits, 2017). Terrestrial subsidies for aquatic ecosystems, primarily governed by gravity, are commonly examined, while fewer works have focused on counter-gravitational biogenic flows from aquatic ecosystems (Baxter et al., 2005; Ballinger and Lake, 2006; Gratton and Vander Zanden, 2009; Epanchin et al., 2010; Bartels et al., 2012; Schulz et al., 2015). One of the main biogenic flows of matter and energy from water to land is provided by emerging aquatic (amphibiotic) insects. The flux of emergent aquatic insects can be comparable or even can exceed the production of terrestrial insects in the surrounding landscape (Gray, 1989; Bartrons et al., 2013). Thus, in many locations, emergent aquatic insects are an important or even principal food supply for many terrestrial consumers, especially for spiders and birds (Nakano and Murakami, 2001; Sanzone et al., 2003; Baxter et al., 2005; Paetzold et al., 2005; Epanchin et al., 2010; Richardson et al., 2010; Schulz et al., 2015).

The quantitative contribution of emergent insects to food webs of a given terrestrial ecosystem is determined by many ecological factors, such as the productivity of aquatic ecosystems and water/land area ratios (ecosystem geometry) (Gratton and Vander Zanden, 2009; Bartrons et al., 2013). Currently, there are several global average estimates of emergence based on local measurements (Baxter et al., 2005; Gladyshev et al., 2009) but only one calculation for a particular landscape (Bartrons et al., 2013). However, specific knowledge of the interrelations of aquatic and terrestrial ecosystems in particular landscapes is necessary to manage these systems for protection of biodiversity and functionality (Ballinger and Lake, 2006; Gratton and Vander Zanden, 2009).

In addition to the quantitative importance for surrounding land ecosystems, the contribution of emergent aquatic insects to terrestrial food webs was recently recognized as being based on their high quality relative to terrestrial food sources (Gladyshev et al., 2009, 2013; Marcarelli et al., 2011; Hixson et al., 2015; Twining et al., 2015; Schindler and Smits, 2017). Currently, food quality is conventionally determined using elemental stoichiometric ratios and amino acid and lipid content and composition (e.g., Anderson et al., 2004; Muller-Navarra, 2008; Marcarelli et al., 2011). Among lipids, long-chain polyunsaturated fatty acids (LC-PUFA) of the omega-3 family, such as eicosapentaenoic acid (20:5n-3, EPA) and docosahexaenoic acid (22:6n-3, DHA), are of key physiological importance for most animals. Indeed, EPA is a biochemical precursor of signalling molecules (endohormones), which control the cardiovascular system, allergic and inflammatory reactions, etc., while DHA regulates the synthesis of endohormones and is the main structural fatty acid of membranes in the brain and retina cells as well as in those of mitochondria in high-frequency contraction skeletal muscles (Simopoulos, 
2000; Infante et al., 2001; Lauritzen et al.,2001; Heckmann et al., 2008; Ahlgren et al., 2009; Wall et al., 2010; Norris and Dennis, 2012).

The parent acid of omega-3 family, alpha-linolenic acid (18:3n-3, ALA), is synthesized only by plants, while animals cannot do it, because they (except the nematode Caenorhabditis elegans) do not have key enzymes, delta-15/omega-3 desaturases (Sperling et al., 2003; Sayanova et al., 2006; Uttaro, 2006; Lands, 2009; Alloatti et al., 2011; Zhou et al., 2011). Terrestrial vascular plants cease their synthesis of omega-3 acids on the 18-carbon ALA, which is the main constituent of membranes of chloroplasts, i.e., stores primarily in green parts of plants (Heinz, 1993; Sayanova et al., 2006). In general, animals, including humans, can convert the parent alpha-linolenic acid, obtained from plants, to physiologically important long-chain EPA and DHA (Stark et al., 2008). Strictly herbivorous terrestrial animals, which consume green parts of plants, evidently can satisfy their ewn-physiological requirements in the long-chain PUFA by the conversion of ALA only (Wood et al., 2008; Kang et al., 2010; Kouba and Mourot, 2011). Specifically, herbivorous terrestrial insects use LC-PUFA primarily as precursors of signalling molecules, eicosanoids, and thereby synthesize them in small quantities, on the level of vitamin requirements (Stanley and Kim, 2014). However, some omnivorous and carnivorous animals cannot cover their physiological requirements in EPA and DHA via the conversion of ALA, thereby they must obtain these essential long chain PUFA from food (Davis \& Kris Etherton, 2003; Green et al., 2004; $\Lambda$ bba et al., 2005; Wall et al., 2010; Twining et al., 2016; 2018; Hadley et al., 2017). Meanwhile in terrestrial ecosystems there are no considerable sources of EPA and DHA for such animals (Gladyshev et al., 2013; Hixson et al., 2015; Twining et al.,

2015). In contrast, some omnivorous and carnivorous terrestrial animals deposit appreciable amounts of EPA and DHA in their specific tissues that are unlikely supported only by the products of ALA conversion (Davis \& Kris-Etherton, 2003; Green et al., 2004; Abba et al., 2005; Wall et al., 2010; Twining et al., 2016; 2018; Hadley et al., 2017). The direct food sources of EPA and DHA may be of crucial importance for such animals, although terrestrial production is known to be poor in these compounds (Gladyshev et al., 2013; Hixson et al., 2015; Twining et al., 2015).

In contrast to terrestrial vascular plants, some taxa of microalgae are capable of synthesizing large amounts of EPA and DHA (Harwood, 1996; Uttaro, 2006; Ruiz-Lopez et al., 2012). EPA and DHA are transferred through aquatic food chains to organisms of progressively higher trophic levels and are then exported to terrestrial ecosystems via vectors such as emerging aquatic insects (Gladyshev et al., 2009, 2013). Emerging aquatic insects were found to be the high-quality food regarding LC-PUFA contents, which support significantly better conditions of 
some insectivorous birds and spiders compared to terrestrial insects (Twining et al., 2016; 2018; Fritz et al., 2017).

Thus, aquatic insects subsidize terrestrial ecosystems with unique molecules, the omega-3 LC-PUFA-which are essential crucial for many physiological processes in some terrestrial animals. The magnitude of these subsidies is poorly known, and the published information remains scattered. Recently, an attempt was made to estimate the export of EPA and DHA from water to land via emergent insects on a global scale (Gladyshev et al., 2009). This coarse estimation gave at least a potential for situations in which there may be a shortage of LC-PUFA for some terrestrial consumers, insectivore rodents (Gladyshev et al., 2009). Nevertheless, it was concluded that to obtain more reliable quantitative estimates data on LC-PUFA fluxes from particular aquatic ecosystems to surrounding terrestrial ecosystems in specific landscapes (biomes) are desirable (Gladyshev et al., 2009).

Then, several direct measurements of the EPA and DHA fluxes in several locations were completed, using quantifications of the emergence and PUFA contents in the emergent biomass (Gladyshev et al., 2011a, b; Borisova et al., 2016; Martin-Creuzburg et al., 2017; Moyo et al., 2017; Popova et al., 2017). To make their local case study data more applicable in a general (worldwide) context, the authors compared data, obtained in their studies with the coarse preliminary estimation of average global PUFA flux made by Gladyshev et al. (2009). However, such comparisons are not conclusive, and more specific estimations of average EPA and DHA fluxes in different types of biomes are desirable (Gladyshev et al., 2009; Schindler and Smits, 2017). Thus, the paper aims to compile a global picture of the LC-PUFA subsidies, their potential size and distribution across biomes.

\section{Material and methods}

\subsection{Calculation of water/land area ratio}

The water/land area ratios in biomes (Olson et al., 2001) were calculated using data from Feng et al. (2016, Table 3 of the reference) and dividing the water area $\left(\mathrm{km}^{2}\right)$ of each biome by its terrestrial area $\left(\mathrm{km}^{2}\right)$.

\subsection{Data on emergence}


To calculate emergence, the available data from the literature in the Web of Science Core Collection were taken. Only reports on emergence calculated in mass, dry mass (DM) or organic carbon units from square metres of a water body for the emergence period (year ${ }^{-1}$ ) for all or dominant emergent taxa were considered. If the same water body was sampled in different years, or closely situated and ecologically similar water bodies from the same landscape were sampled, then the mean overall reported values of the emergence were calculated and used for further meta-analysis, as in similar studies (Bartels et al., 2012).

\subsection{Determining the biome}

To attribute the water bodies where the emergence was measured to a biome, the resource http://worldmap.harvard.edu/maps/6046/ was used. Additionally, to specify the biome, the descriptions of geomorphology and vegetation in relevant papers were considered.

\subsection{Generalization of PUFA contents in emergent insects}

Available data on EPA and DHA contents ( $\mathrm{mg} \mathrm{g}^{-1}$ of dry mass) were extracted from the Web of Science Core Collection. These data were obtained based on an extraction of total lipids by a chloroform (dichloromethane):methanol mixture and gas chromatography (GC) of fatty acids methyl esters (FAME) and internal standards, i.e., they represented quantitative ( $\mathrm{mg} \mathrm{g}^{-1}$ biomass) EPA and DHA estimates (for details, see, e.g., Sushchik et al., 2013). In addition, we included our unpublished data in the analysis, obtained by the above methods (GC of FAME and internal standard), described in detail elsewhere (Sushchik et al., 2013). Since all the data on PUFA contents in emergent aquatic insects were obtained by similar fatty acid analysis methods, they were comparable with each other and with our unpublished data.

When collecting the data for calculating the median PUFA content in emergent insect biomass from the relevant literature and unpublished data, we considered species composition of emergent aquatic insects published in the insect emergence literature (Section2.2 Data on emergence). In most cases, Chironomidae dominated the species composition (up to $\sim 90 \%$ of the biomass of emergent insects), while the remaining species composition consisted of primarily Ephemeroptera, Plecoptera, Trichoptera, and Odonata (Brittain and Lillehammer, 1978; Jackson and Fisher, 1986; Stagliano et al., 1998; Rolauffs et al., 2001; Baxter et al., 2005; MacKenzie, 2005; Paetzold et al., 2005; Rundio and Lindley, 2012; Jonsson and Stenroth, 2016; Yuen and Dudgeon, 2016; Salvarina et al., 2017). In some locations, rather than Chironomidae, Diptera such as Culicidae, Simuliidae and Chaoboridae were the dominant taxa (Whiles and Goldowitz, 
2001; Sushchik et al., 2013; Martin-Creuzburg et al., 2017; Salvarina et al., 2017). Finally, we collected all published data for PUFA contents in imago of Chironomidae (measured in 4 case studies in 4 locations) and in imago ofEphemeroptera, Plecoptera, Trichoptera, Culicidae, Chaoboridae and miscellaneous insects (each taxa was measured in 1 case study in 1 location) and calculated their median value to determine their principal contribution to the biomass of emergent insects in most locations. The median for all taxa was used for the following calculation to estimate the PUFA fluxes from water to land via the emergent insects.

\subsection{Statistics}

Descriptive statistic for biomes with number of data $n \geq 3$, Kolmogorov-Smirnov onesample test for normality $D_{\mathrm{K}-\mathrm{S}}$, standard errors $\mathrm{SE}$, coefficient of variation $C V$, Student's $t$-tests and one-way ANOVA were calculated conventionally, using STATISTICA software, version 9.0 (StatSoft, Inc., Tulsa, OK, USA).

\section{Results}

Data on insect emergence from the surface of water bodies $\left(\mathrm{g} \mathrm{DM} \mathrm{m}^{-2}\right.$ year $\left.^{-1}\right)$ were available only for 8 biomes (Table 1). The highest value of emergence was reported for a South African river (tropical and subtropical moist broadleaf forests biome) (Table 1). A high value of emergence was also reported for a desert creek (deserts and xeric shrublands biome) (Table 1). However, only single observations were available from these two biome types.

For three biomes with number of data $n \geq 3$ descriptive statistics was calculated (Table 1). All data for these three biomes had normal distribution. In biome Tropical and Subtropical Moist Broadleaf Forests average value of emergence was higher, than those for biomes Temperate Broadleaf and Mixed Forests and Temperate Grasslands, Savannas and Shrublands (Table 1). Nevertheless, because of a high coefficient of variation, which value was nearly $100 \%$, average value of emergence in Tropical and Subtropical Moist Broadleaf Forests did not differ significantly from those of two other biomes according to Student's $t$-tests and one-way ANOVA.

The sum of EPA and DHA in the biomass of imago of emergent insects varied from 7.96 to $33.7 \mathrm{mg} \cdot \mathrm{g}^{-1}$ of dry mass, with median value $11.4 \mathrm{mg} \cdot \mathrm{g}^{-1}$ (Table 2 ).

Among the 13 biomes, apart from mangroves, the highest water/land area ratio was characteristic of the tundra biome (Table 3). The tropical and subtropical coniferous forests 
biome had the lowest ratio (Table 3). Multiplying the values of the water/land area ratios (Table 3 ) by the respective values of emergence from the water area (Table 1), values of emergence were obtained for each biome (Table 3). Then, using the median value of EPA+DHA contents in the biomass of emergent insects (Table 2), fluxes of these PUFA from aquatic ecosystems in the biomes were calculated (Table 3). The highest emergence and concomitant PUFA flux values were characteristic of tropical and subtropical moist broadleaf forests (Table 3). Surprisingly, the deserts and xeric shrublands biome also had high emergence and concomitant PUFA flux values, while the minimum values were in the temperate coniferous forests biome (Table 3). Data on 6 biomes were absent (Table 3).

\section{Discussion}

The main findings of this study are follows. The first generalization of LC-PUFA contents in imago of emergent aquatic insects was done and $\sim 4$-fold variations of the reported values, from $\sim 8$ to $\sim 34 \mathrm{mg} \cdot \mathrm{g}^{-1} \mathrm{DM}$ was found (Table 2). Most likely, when more samples are analysed throughout the world, the range of variations will be expanded. Indeed, variations of EPA+DHA contents in the benthic larvae of aquatic insects were $~ 10$-fold (Makhutova et al., 2016). Besides, the average LC-PUFA flux to land area was found to vary from 0.04 to 4.39 $\mathrm{mg} \cdot \mathrm{m}^{-2} \cdot \mathrm{year}^{-1}$ across numerous biomes. According to previous estimations, the average global flux of EPA+DHA by emergent insects could be from 2.5 to $11.8 \mathrm{mg} \cdot \mathrm{m}^{-2} \cdot \mathrm{year}^{-1}$ (Gladyshev et al., 2009).

Since our calculations gave the lower LC-PUFA supply, the putative limitation of some terrestrial consumers by these essential biochemical compounds (Gladyshev et al., 2009) may be more severe than was previously thought. These terrestrial consumers, which seem be limited by a shortage of supply of aquatic EPA and DHA, are some insectivore birds. For instance, insectivore birds that evolve with access to aquatic insects seem to be limited by a shortage of supply of aquatic EPA and DHA. Twining et al. (2018) found that tree swallow (Tachycineta bicolor, Passeriformes) cannot cover their LC-PUFA demands by the synthesis from dietary ALA precursor and thereby mustobtain most EPA and DHA from the direct food sources, aquatic insects. Thus, terrestrial insects, which contain no detectable quantities of EPA and DHA in their biomass (Stanley-Samuelson et al., 1988; Rumpold and Schluter, 2013; Barroso et al., 2014; Sanchez-Muros et al., 2014), would not compensate dietary needs of tree swallows and other aerial insectivores with similar niches with respect to LC-PUFA (Twining et al., 2018). Besides the birds, insectivorous rodents may be limited by the putative aquatic LC-PUFA shortage, as well as wolf spiders (Fritz et al., 2017). 
Meanwhile, the paper recognizes the lack of reliable information on the global demand of terrestrial consumers in EPA and DHA and relative contribution of their synthesis from ALA precursor vs the flux from aquatic ecosystems, as well as the fraction of the aquatic production of LC-PUFA which is transferred to land consumers.

Among biomes, the highest emergence and concomitant PUFA flux values were found in tropical and subtropical moist broadleaf forests. On the one hand, this seems to be reasonable, considering the comparatively high biological productivity and humidity of this biome. On the other hand, the high estimate was evidently due to only one extremely high value of emergence obtained from South African river, but in other locations of this biome the values of emergence were approximately an order of magnitude lower (Table 1). Thus, additional studies are necessary to confirm this preliminary estimate.

Calculating the emergence to land area, we used the water/land area ratio and uniformly distributed the aquatic biomass through the whole biome territory. However, many authors reported that the flux of aquatic productivity decays exponentially and is deposited within $\sim 100$ $m$ inland from the shore (Delettre et al., 2000; Gratton and Vander Zanden, 2009; Bartrons et al., 2013; Korobushkin, 2014; Muehlbauer et al., 2014; Korobushkin et al., 2016; Schindler and Smits, 2017). Nevertheless, there are several circumstances that justify our assumption of the uniform distribution of emergent insects. First, large insects, such as odonates, are strong fliers and can move several kilometres from waterbodies inside terrestrial habitat (Gratton and Vander Zanden, 2009; Popova et al., 2017). Second, when terrestrial birds, which visit waterbodies and riparian zones to consume emergent insects, return to their inland nest sites, they transport aquatic productivity for several kilometres, providing spatial integration of the aquatic subsidies (e.g., Epanchin et al., 2010; Schindler and Smits, 2017). In addition, even if the spatial extent of emergent insects is within several metres from the edge of the water, the overall spatial extent of the exchange in many landscapes may be high because of the dendritic form of drainage networks and meander bends of waterbodies, which provide substantial overlap of the deposition areas (Sabo et al., 2012). Indeed, Bartrons et al. (2013) used detailed geographical information for the state of Wisconsin to determine that approximately $20 \%$ of the total land area of Wisconsin falls within $100 \mathrm{~m}$ of a lake or stream. Assuming the aquatic insect deposition is within $100 \mathrm{~m}$ inland from the shore, using detailed geographical data on the area of lakes and rivers and estimating the emergence based on benthic insect production, Bartrons et al. (2013) calculated the total annual insect emergence in the state of Wisconsin as 6,800 metric tons of organic carbon (C).It is worth noting, that $\sim 20 \%$ of the total land area of Wisconsin falls within $100 \mathrm{~m}$ of a lotic or lentic waterbody (Bartrons et al. 2013).Now let's determinethe emergence in Wisconsin using our more coarse way of calculations. Taking the area of Wisconsin as 169639 
$\mathrm{km}^{2}$ and the total water area in this state as $10950 \mathrm{~km}^{2}$ (Table 2 in Bartrons et al., 2013) and taking $1 \mathrm{~g} \mathrm{C}=2.75 \mathrm{~g} \mathrm{DM}$ (Alimov, 1989), the emergence in Wisconsin was $0.12 \mathrm{~g} \mathrm{DM} \cdot \mathrm{m}^{-2}$. year $^{-1}$. Wisconsin is in the temperate broadleaf and mixed forests biome. According to our calculations, the average emergence to land area in this biome was $0.119 \mathrm{~g} \mathrm{DM} \cdot \mathrm{m}^{-2} \cdot \mathrm{year}^{-1}$ (Table 4). Here, we see good similarity between the calculations, based on detailed geographical information for the actual landscape, the state of Wisconsin (Bartrons et al., 2013), and our global-scale calculations, which are inevitably based on a number of simplifications and assumptions. Hence, more work on actual landscapes based on fine-scale geographical information (e.g., Bartrons et al., 2013; Popova et al., 2017) are desirable to specify the areal flux of aquatic productivity via emergent insects.

\section{Conclusions}

The study demonstrated the high variability of the aquatic LC-PUFA fluxes via emergent insects among biomes and gave a benchmark for future studies in particular landscapes. The present calculations give lower values of the aquatic PUFA flux to land area than were previously determined. Thus, taking into account the sparse but clear evidence of the possible limitation of some terrestrial consumers by a shortage of essential PUFA, the quantification of EPA and DHA fluxes via emergent aquatic insects for actual landscapes is believed to be important for theoretical and applied ecology.

\section{Acknowledgements}

The work was supported by the project of Siberian Federal University, carried out according to Federal Tasks of Ministry of Education and Science of the Russian Federation No.

6.1504.2017/PCh and by Russian Federal Tasks of Fundamental Research (project No.

51.1.1).We are grateful to two anonymous Reviewers for their kind help to significantly improve the manuscript.

\section{References}

Abba, C., Mussa, P.P., Vercelli, A., Raviri, G., 2005. Essential fatty acids supplementation in different-stage atopic dogs fed on a controlled diet. J. Anim. Physiol. Anim. Nutr.89, 203207. 
Ahlgren, G., Vrede, T.,Goedkoop, W., 2009.Fatty acid ratios in freshwater fish, zooplankton and zoobenthos - are their specific optima? In: Arts, M.T., Kainz,M., Brett,M.T. (Eds.), Lipids in aquatic ecosystems.Springer, New York,pp.147-178.

Alimov, A.F., 1989. An introduction to production hydrobiology. Gidrometeoizdat, Leningrad. (in Russian).

Alloatti, A., Uttaro, A.D. 2011. Highly specific methyl-end fatty-acid desaturases of trypanosomatids. Mol. Biochem. Parasitol. 175, 126-132.

Anderson, T.R., Boersma, M., Raubenheimer D., 2004. Stoichiometry: linking elements to biochemicals. Ecology85,1193-1202.

Ballinger, A., Lake, P.S., 2006. Energy and nutrient fluxes from rivers and streams into terrestrial food webs. Mar. Freshwater Res. 57,15-28.

Barroso, F. G., de Haro, C., Sanchez-Muros, M.J., Venegas, E., Martinez-Sanchez, A., PerezBan, C., 2014. The potential of various insect species for use as food for fish. Aquaculture 422-423, 193-201.

Bartels, P., Cucherousset, J., Steger, K., Eklov, P., Tranvik, L.J., Hillebrand, H., 2012. Reciprocal subsidies between freshwater and terrestrial ecosystems structure consumer resource dynamics. Ecology 93, 1173-1182.

Bartrons, M., Papes, M., Diebel, M. W., Gratton, C., Vander Zanden, M. J., 2013. Regional-level inputs of emergent aquatic insects from water to land. Ecosystems 16, 1353-1363.

Baxter, C.V., Fausch, K.D., Saunders, W.C., 2005. Tangled webs: reciprocal flows of invertebrate prey link streams and riparian zones. Freshwater Biol. 50, 201-220.

Borisova, E.V., Makhutova, O.N., Gladyshev, M.I., Sushchik, N.N., 2016. Fluxes of biomass and essential polyunsaturated fatty acids from water to land via chironomid emergence from a mountain lake. Contemp. Probl. Ecol. 9, 446-457.

Brittain, J.E., Lillehammer, A., 1978. The fauna of the exposed zone of Ovre Heimdalsvatn: methods, sampling stations and general results. Holarctic Ecol. 1, 221-228.

Davis, B.C, Kris-Etherton, P.M., 2003. Achieving optimal essential fatty acid status in vegetarians: current knowledge and practical implications. Am. J. Clin. Nutr. 78, 640S$646 \mathrm{~S}$.

Delettre, Y.R., Morvan N., 2000. Dispersal of adult aquatic Chironomidae (Diptera) in agricultural landscapes. Freshwater Biol. 44, 399-411.

Djomina I.V., Yermokhin M.V., Polukonova N. V., 2016. Substance and energy flows formed by the emergence of amphibiotic insects across the water-air boundary on the floodplain lakes of the Volga River. Contemp. Probl. Ecol. 9, 407-420. 
Dreyer, J., Townsend, P.A., Hook III, J.C., Hoekman, D., Vander Zanden, M.J., Gratton , C., 2015. Quantifying aquatic insect deposition from lake to land. Ecology 96, 499-509.

Epanchin, P.N., Knapp, R.A., Lawler, S.P., 2010. Nonnative trout impact an alpine-nesting bird by altering aquatic-insect subsidies. Ecology 91, 2406-2415.

Feng, M., Sexton, J.O., Channan, S., Townshend J.R., 2016 A global, high-resolution (30-m) inland water body dataset for 2000: first results of a topographic-spectral classification algorithm. Int. J. Digit. Earth 9, 113-133.

Francis, T.B., Schindler, D.E., Moore J.W., 2006. Aquatic insects play a minor role in dispersing salmon-derived nutrients in southwestern Alaska. Can. J. Fish. Aquat. Sci. 63, 2543-2552.

Freitag, H., 2004. Composition and longitudinal patterns of aquatic insect emergence in small rivers of Palawan Island, the Philippines. Int. Rev. Hydrobiol. 89,375-391.

Fritz, K.A., Kirschman, L.J., McCay, S.D., Trushenski, J.T., Warne, R.W., Whiles, M.R., 2017.

Subsidies of essential nutrients from aquatic environments correlate with immune function in terrestrial consumers. Freshw. Sci. 36, 893-900.

Gladyshev, M.I., Arts, M.., Sushchik, N.N., 2009. Preliminary estimates of the export of omega3 highly unsaturated fatty acids (EPA+DHA) from aquatic to terrestrial ecosystems. In: Arts, M.T., Kainz, M., Brett, M.T. (Eds.), Lipids in aquatic ecosystems. Springer, New York, pp. 179-209.

Gladyshev, M. I., Kharitonov, A. Y., Popova, O. N., Sushchik, N. N., Makhutova, O. N., Kalacheva, G. S. (2011a). Quantitative estimation of dragonfly role in transfer of essential polyunsaturated fatty acids from aquatic to terrestrial ecosystems. Dokl. Biochem. Biophys. 438,141-143.

Gladyshev, M.I., Sushchik, N.N., Makhutova, O.N., 2013. Production of EPA and DHA in aquatic ecosystems and their transfer to the land. Prostaglandins Other Lipid Mediators $107,117-126$.

Gladyshev, M.I., Sushchik, N.N., Yurchenko, Y.A., Belevich, O.E., Kalacheva, G.S. 2011 b. Differences in the fatty acid compositions of blood-sucking mosquito larvae and imagoes and the water-to-land export of essential acids. Dokl. Biol. Sci. 441, 385-388.

Gratton, C., Vander Zanden, M.J., 2009. Flux of aquatic insect productivity to land: comparison of lentic and lotic ecosystems. Ecology 90, 2689-2699.

Gray, L.J., 1989. Emergence production and export of aquatic insects from a tallgrass prairie stream. Southwest. Nat. 34, 313-318.

Green, K.H., Wong, S.C.F., Weiler, H.A., 2004. The effect of dietary n-3 long-chain polyunsaturated fatty acids on femur mineral density and biomarkers of bone metabolism in 
healthy, diabetic and dietary-restricted growing rats. Prostaglandins Leukotrienes Essent. Fatty Acids 71, 121-130.

Hadley, K.B., Bauer, J., Milgram, N.W., 2017. The oil-rich alga Schizochytrium sp. as a dietary source of docosahexaenoic acid improves shape discrimination learning associated with visual processing in a canine model of senescence. Prostaglandins, Leukotrienes Essent. Fatty Acids 118, 10-18.

Harwood, J.L., 1996. Recent advances in the biosynthesis of plant fatty acids. Biochim. Biophys. Acta 1301, 7-56.

Heckmann, L.H., Sibly, R.M., Timmermans, M J.T.N., Callaghan, A., 2008. Outlining eicosanoid biosynthesis in the crustacean Daphnia. Fron. Zool. 5, 11.

Heinz, E., 1993. Biosynthesis of polyunsaturated fatty acids. In: Moore, T.S. (Ed.),Lipid metabolism in plants. CRC, Boca Raton, pp. 34-89.

Hixson, S.M., Sharma, B., Kainz, M.J., Wacker, A., Arts, M.T., 2015. Production, distribution, and abundance of long-chain omega-3 polyunsaturated fatty acids: a fundamental dichotomy between freshwater and terrestrial ecosystems. Environ. Rev.23,414-424.

Infante, J.P., Kirwan, R.C., Brenna, J.T., 2001. High levels of docosahexaenoic acid (22:6n-3)containing phospholipids in high-frequency contraction muscles of hummingbirds and rattlesnakes. Comp. Biochem. Physiol., Part B 130, 291-298.

Jackson, J.K, Fisher, S.G., 1986. Secondary production, emergence, and export of aquatic insects of a Sonoran desert stream. Ecology 67,629-638.

Johnson, B.R., Fritz, K.M., Price, R., 2013. Estimating benthic secondary production from aquatic insect emergence in streams affected by mountain top removal coal mining, West Virginia, USA. Fundam. Appl. Limnol. 182, 191-204.

Jonsson, M., Stenroth, K., 2016. True autochthony and allochthony in aquatic-terrestrial resource fluxes along a landuse gradient. Freshwater Sci. 35, 882-894.

Kang, X., Bai Y., Sun G., Huang Y., Chen Q., Han R., Li G., Li F., 2010. Molecular cloning, characterization, and expression analysis of chicken $\Delta-6$ desaturase. Asian-Aust. J. Anim. Sci. 23, 116-121.

Korobushkin, D.I., 2014. Role of allochthonous carbon in the energy of terrestrial invertebrate communities at different distances from the Black Sea and a freshwater lake (isotopic evidence). Russ. J. Ecol. 45, 223-230.

Korobushkin D.I., Korotkevich A.Y., Kolesnikova A.A., Goncharova A.A., Panchenkova A.A., Tiunov A.V., 2016. Consumption of aquatic subsidies by soil invertebrates in coastal ecosystems. Contemp. Probl. Ecol. 9, 396-406. 
Kouba, M., Mourot, J., 2011. A review of nutritional effects on fat composition of animal products with special emphasis on n-3 polyunsaturated fatty acids. Biochimie 93, 13-17.

Lands W.E.M., 2009. Human life: caught in the food web. In: Arts, M.T., Kainz, M., Brett, M.T.(Eds.), Lipids in aquatic ecosystems. Springer, New York, pp. 327-354.

Lauritzen, L., Hansen, H.S., Jorgensen, M.H., Michaelsen, K.F., 2001. The essentiality of long chain n-3 fatty acids in relation to development and function of the brain and retina. Prog. Lipid Res. 40, 1-94.

Leeper, D.A., Taylor, B.E., 1998. Insect emergence from a South Carolina (USA) temporary wetland pond, with emphasis on the Chironomidae (Diptera). J. North Am. Benthological Soc. $17,54-72$.

MacKenzie, R.A., 2005. Spatial and temporal patterns in insect emergence from a southern Maine salt marsh. Am. Midl. Nat.153, 257-269.

MacKenzie, R.A., Kaster, J.L., 2004. Temporal and spatial patterns of insect emergence from a Lake Michigan coastal wetland. Wetlands 24, 688-700.

Makhutova, O.N., Borisova, E.V., Shulepina, S.P., Kolmakova, A.A., Sushchik, N.N., 2017. Composition and content of Fluxes of fatty acids of dominant chironomid species from a salt Siberian lake at different development stages. Contemp. Probl. Ecol. (accepted for publication).

Makhutova, O.N., Shulepina, S.P., Sharapova, T.A., Dubovskaya, O.P., Sushchik, N.N., Baturina, M.A., Pryanichnikova, E.G., Kalachova, G.S., Gladyshev, M.I., 2016. Content of polyunsaturated fatty acids essential for fish nutrition in zoobenthos species. Freshwater Sci. 35, 1222-1234.

Marcarelli, A.M., Baxter,C.V., Mineau, M.M., Hall, R.O.Jr., 2011. Quantity and quality: unifying food web and ecosystem perspectives on the role of resource subsidies in freshwaters. Ecology 92, 1215-1225.

Martin-Creuzburg, D., Kowarik, C., Straile D., 2017. Cross-ecosystem fluxes: Export of polyunsaturated fatty acids from aquatic to terrestrial ecosystems via emerging insects. Sci.Total Environ. 577, 174-182.

Moyo, S., Chari, L.D., Villet M.H., Richoux, N.B., 2017. Decoupled reciprocal subsidies of biomass and fatty acids in fluxes of invertebrates between a temperate river and the adjacent land. Aquat. Sci. DOI 10.1007/s00027-017-0529-0.

Muehlbauer, J.D., Collins, S.F., Doyle, M.W., Tockner, K., 2014. How wide is a stream? Spatial extent of the potential "stream signature" in terrestrial food webs using meta-analysis. Ecology 95, 44-55. 
Muller-Navarra, D. C. (2008). Food web paradigms: the biochemical view on trophic interactions. Int. Rev. Hydrobiol.93, 489-505.

Nakano, S., Murakami, M., 2001. Reciprocal subsidies: Dynamic interdependence between terrestrial and aquatic food webs. Proc. Natl. Acad. Sci. U. S. A. 98, 166-170.

Norris, P.C., Dennis, E.A., 2012. Omega-3 fatty acids cause dramatic changes in TLR4 and purinergic eicosanoid signaling. Proc. Natl. Acad. Sci. U. S. A.109, 8517-8522.

Olson, D.M., Dinerstein, E., Wikramanayake, E.D., Burgess, N.D., Powell, G.V.N., Underwood, E.C., D'amico, J.A., Itoua, I., Strand, H.E., Morrison, J.C., Loucks, C.J., Allnutt, T.F., Ricketts, T.H., Kura, Y., Lamoreux, J.F., Wettengel, W.W., Hedao, P., Kassem, K.R., 2001. Terrestrial ecoregions of the world: a new map of life on Earth. BioScience 51, 933938.

Paasivirta, L., Lahti, T., Peratie, T., 1988. Emergence phenology and ecology of aquatic and semi-terrestrial insects on a boreal raised bog in central Finland. Holarctic Ecol. 11, 96105.

Paetzold, A., Schubert, C. J., Tockner K., 2005. Aquatic terrestrial linkages along a braidedriver: riparian arthropods feeding on aquatic insects. Ecosystems, 8: 748-759.

Poepperl, R., 2000. Benthic secondary production and biomass of insects emerging from a northern German temperate stream. Freshwater Biol. 44, 199-211.

Popova, O.N., Haritonov, A.Y., Sushchik, N.N., Makhutova, O.N., Kalachova, G.S., Kolmakova, A.A., Gladyshev, M.I., 2017. Export of aquatic productivity, including highly unsaturated fatty acids, to terrestrial ecosystems via Odonata. Sci. Total Environ.581-582, $40-48$.

Richardson, J.S., Zhang, Y., Marczak, L.B., 2010. Resource subsidies across the land-freshwater interface and responses in recipient communities. River Res. Appl.26,55-66.

Rolauffs, P., Hering, D., Lohse, S., 2001. Composition, invertebrate community and productivity of a beaver dam in comparison to other stream habitat types. Hydrobiologia 459, 201-212.

Ruiz-Lopez, N., Sayanova, O., Napier, J.A., Haslam, R.P., 2012. Metabolic engineering of the omega-3 long chain polyunsaturated fatty acid biosynthetic pathway into transgenic plants. J. Exp. Bot. 63, 2397-2410.

Rumpold, B.A., Schluter, O.K., 2013. Nutritional composition and safety aspects of edible insects. Mol. Nutr. Food Res. 57, 802-823.

Rundio, D.E., Lindley, S.T., 2012. Reciprocal fluxes of stream and riparian invertebrates in a coastal California basin with Mediterranean climate. Ecol. Res.27, 539-550.

Sabo, J.L., Hagen, E.M., 2012. A network theory for resource exchange between rivers and their watersheds. Water Resour. Res. 48, W04515, P.1-17, doi: 10.1029/2011WR010703 
Salvarina, I., Gravier, D., Rothhaupt, K.-O., 2017. Seasonal insect emergence from three different temperate lakes. Limnologica 62, 47-56.

Sanchez-Muros, M.-J., Barroso, F.G., Manzano-Agugliaro, F., 2014. Insect meal as renewable source of food for animal feeding: a review. J. Cleaner Prod. 65, 16-27.

Sanzone, D.M., Meyer, J.L., Marti, E., Gardiner, E.P., Tank, J.L., Grimm, N.B., 2003. Carbon and nitrogen transfer from a desert stream to riparian predators. Oecologia 134, 238-250.

Sayanova, O., Haslam, R., Guschina, I., Lloid, D., Christie ,W.W., Harwood, J.L.,Napier, J.A.,2006. A bifunctional $\Delta 12, \Delta 15$-desaturase from Acanthamoeba castellanii directs the synthesis of highly unusual n-1 series unsaturated fatty acids. J. Biol. Chem. 281, 3653336541.

Schindler, D.E., Smits, A.P., 2017. Subsidies of aquatic resources in terrestrial ecosystems. Ecosystems 20, 78-93.

Schulz, R., Bundschuh, M., Gergs, R., Brühl, C. A., Diehl, D., Entling, M. H., Fahse, L., Frör, O., Jungkunst, H. F., Lorke, A., Schäfer, R. B., Schaumann, G. E., Schwenk, K., 2015. Review on environmental alterations propagating from aquatic to terrestrial ecosystems. Sci. Total Environ. 538, 246-261.

Sherk, T., Rau, G., 1992. Emergence of Chironomidae from Findley Lake and two ponds in the Cascade Mountains, U.S.A. Netherlands J. Aquat. Ecol. 26, 321-330.

Silina, A.E., 2016. Emergence of amphibiotic insects from a floodplain lake in the Usman Forest in the Central Russian Forest Steppe. Contemp. Probl. Ecol. 9,421-436.

Simopoulos, A.P. 2000. Human requirement for n-3 polyunsaturated fatty acids. Poult. Sci. 79, 961-970.

Sperling, P., Ternes, P., Zank, T.K., Heinz, E.,2003. The evolution of desaturases.

Prostaglandins, Leukotriens Essent. Fatty Acids68,73-95.

Stagliano, D.M., Benke, A.C., Anderson, D.H., 1998. Emergence of aquatic insects from 2 habitats in a small wetland of the southeastern USA: temporal patterns of numbers and biomass. J. North Am. Benthological Soc.17, 37-53.

Stanley, D., Kim, Y., 2014. Eicosanoid signaling in insects: from discovery to plant protection. Crit. Rev. Plant Sci. 33, 20-63.

Stark, A.H., Crawford, M.A, Reifen, R., 2008. Update on alpha-linolenic acid. Nutr. Rev. 66, $326-332$.

Sushchik, N.N., Yurchenko, Y.A., Gladyshev, M.I., Belevich, O.E., Kalachova, G.S., Kolmakova, A.A., 2013. Comparison of fatty acid contents and composition in major lipid classes of larvae and adults of mosquitoes (Diptera: Culicidae) from a steppe region. Insect Sci. 20, 585-600. 
Twining, C.W., Brenna, J.T., Hairston, Jr.N.G., Flecker, A.S., 2015. Highly unsaturated fatty acids in nature: what we know and what we need to learn. Oikos 125, 749-760.

Twining, C.W., Brenna, J.T., Lawrence, P., Shipley, J.R., Tollefson, T.N., Winkler, D.W., 2016. Omega-3 long-chain polyunsaturated fatty acids support aerial insectivore performance more than food quantity. Proc. Natl. Acad. Sci. U.S.A. 113,10920-10925.

Twining, C.W., Lawrence, P., Winkler, D.W., Flecker, A.S., Brenna, J.T., 2018. Conversion efficiency of $\alpha$-linolenic acid to omega-3 highly unsaturated fatty acids in aerial insectivore chicks. J. Exp. Biol. 221, jeb165373.

Uttaro, A.D., 2006. Biosynthesis of polyunsaturated fatty acids in lower eukaryotes. IUBMB Life 58, 563-571.

Wall, R., Ross, R.P., Fitzgerald, G.F., Stanton, C., 2010. Fatty acids from fish: the antiinflammatory potential of long-chain omega-3 fatty acids. Nutr. Rev. 68, 280-289.

Whiles, M.R., Goldowitz, B.S., 2001. Hydrologic influences on insect emergence production from central Platte river wetlands. Ecol. Appl. 11, 1829-1842.

Wood, J.D., Enser, M., Fisher, A.V., Nute, G.R.,Sheard, P.R., Richardson, R.I., Hughes, S.I., Whittington, F.M., 2008. Fat deposition, fatty acid composition and meat quality: A review. Meat. Sci. 78, 343-358.

Woollhead, J., 1994. Birds in the trophic web of Lake Esrom, Denmark.Hydrobiologia 279/280, $29-38$.

Yuen, E.Y.L., Dudgeon, D., 2016. The magnitude and seasonality of aquatic insect subsidies to tropical stream riparia in Hong Kong. Aquat. Sci.78, 655-667.

Zhou, X.-R., Green, A.G., Singh, S.P.,2011. Caenorhabditis elegans $\Delta 12$-desaturase FAT-2 is a bifunctional desaturase able to desaturate a diverse range of fatty acid substrates at the $\Delta 12$ and $\Delta 15$ positions. J. Biol. Chem.286,43644-43650. 


\section{Table 1}

Insect emergence from the water surfaces $\left(\mathrm{g} \mathrm{DM} \mathrm{m}^{-2} \mathrm{year}^{-1}\right)$ in biomes. Accounted (dominant) taxa: D - Diptera, Ch - Chironomidae, C - Culicidae, E - Ephemeroptera, O - Odonata, P Plecoptera, T - Trichoptera, $\mathrm{W}$ - whole community.

\begin{tabular}{|c|c|c|c|}
\hline Water body & Taxa & Emergence & Reference \\
\hline \multicolumn{4}{|c|}{ Tundra } \\
\hline lake $\left(61^{\circ} \mathrm{N} 9^{\circ} \mathrm{E}\right)$ & $\mathrm{W}$ & $0.1^{\mathrm{a}}$ & Brittain and Lillehammer, 1978 \\
\hline $\operatorname{creek}\left(59^{\circ} 20^{\prime} \mathrm{N} 158^{\circ} 40^{\prime} \mathrm{W}\right)$ & $\mathrm{E}, \mathrm{P}, \mathrm{T}$ & 0.4 & Francis et al., 2006 \\
\hline Average & & 0.3 & \\
\hline \multicolumn{4}{|c|}{ Boreal Forests/Taiga } \\
\hline $\operatorname{bog}\left(61^{\circ} 41^{\prime} \mathrm{N}, 24^{\circ} 06^{\prime} \mathrm{E}\right)$ & $\mathrm{Ch}$ & $1.1^{\mathrm{b}}$ & Paasivirta et al., 1988 \\
\hline lake $\left(65^{\circ} 36^{\prime} \mathrm{N}, 17^{\circ} 00^{\prime} \mathrm{W}\right)$ & $\mathrm{Ch}$ & 1.9 & Dreyer et al., 2015 \\
\hline Average & & 1.5 & \\
\hline \multicolumn{4}{|c|}{ Temperate Coniferous Forests } \\
\hline lake $\left(47^{\circ} \mathrm{N} 121^{\circ} \mathrm{W}\right)$ & $\mathrm{Ch}$ & $0.2^{\mathrm{c}}$ & Sherk and Rau, 1992 \\
\hline lake $\left(52^{\circ} 50^{\prime} \mathrm{N} 93^{\circ} 14^{\prime} \mathrm{E}\right)$ & $\mathrm{Ch}$ & 0.2 & Borisova et al., 2016 \\
\hline Average & & 0.2 & \\
\hline \multicolumn{4}{|c|}{ Temperate Broadleaf and Mixed Forests } \\
\hline streams $\left(47^{\circ} \mathrm{N} 15^{\circ} \mathrm{E}\right)$ & $\mathrm{E}, \mathrm{P}, \mathrm{T}$ & $4.3^{\mathrm{d}}$ & Jackson and Fisher, 1986 \\
\hline streams \& springs $\left(51^{\circ} \mathrm{N} 10^{\circ} \mathrm{E}\right)$ & $\mathrm{W}$ & $3.2^{\mathrm{e}}$ & Jackson and Fisher, 1986 \\
\hline river $\left(45^{\circ} \mathrm{N} 74^{\circ} \mathrm{W}\right)$ & $\mathrm{W}$ & $6.2^{\mathrm{f}}$ & Jackson and Fisher, 1986 \\
\hline lake $\left(59^{\circ} \mathrm{N} 18^{\circ} \mathrm{E}\right)$ & $\mathrm{Ch}$ & $1.9^{\mathrm{g}}$ & Jackson and Fisher, 1986 \\
\hline lake $\left(56^{\circ} \mathrm{N} 12^{\circ} \mathrm{E}\right)$ & $\mathrm{W}$ & $1.3^{\mathrm{a}}$ & Woollhead, 1994 \\
\hline wetland pond $\left(33^{\circ} \mathrm{N} 81^{\circ} \mathrm{W}\right)$ & $\mathrm{Ch}$ & $1.1^{\mathrm{h}}$ & Leeper and Taylor, 1998 \\
\hline wetland pond $\left(32^{\circ} 52^{\prime} \mathrm{N} 87^{\circ} 26^{\prime} \mathrm{W}\right)$ & $\mathrm{Ch}$ & $1.5^{\mathrm{b}}$ & Stagliano et al., 1998 \\
\hline stream $\left(54^{\circ} \mathrm{N} 10^{\circ} \mathrm{E}\right)$ & $\mathrm{D}, \mathrm{T}, \mathrm{E}$ & 1.7 & Poepperl, 2000 \\
\hline brook $\left(51^{\circ} \mathrm{N} 6^{\circ} \mathrm{E}\right)$ & $\mathrm{Ch}$ & $10.4^{\mathrm{b}}$ & Rolauffs et al., 2001 \\
\hline stream $\left(42^{\circ} 43^{\prime} \mathrm{N} 141^{\circ} 36^{\prime} \mathrm{E}\right)$ & $\mathrm{W}$ & $1.2^{\mathrm{i}}$ & Nakano and Murakami, 2001 \\
\hline wetland $\left(44^{\circ} \mathrm{N} 87^{\circ} 39^{\prime} \mathrm{W}\right)$ & $\mathrm{O}, \mathrm{E}$ & 0.5 & MacKenzie and Kaster, 2004 \\
\hline salt marsh $\left(43^{\circ} \mathrm{N} 70^{\circ} \mathrm{W}\right)$ & $\mathrm{Ch}$ & $0.2^{\mathrm{h}}$ & MacKenzie, 2005 \\
\hline river $\left(46^{\circ} \mathrm{N} 12^{\circ} 30^{\prime} \mathrm{E}\right)$ & $\mathrm{P}, \mathrm{E}, \mathrm{Ch}$ & 6.3 & Paetzold et al., 2005 \\
\hline stream $\left(38^{\circ} \mathrm{N} 81^{\circ} \mathrm{W}\right)$ & Ch, P, T & $3.7^{\mathrm{j}}$ & Johnson et al., 2013 \\
\hline lake $\left(51^{\circ} 48^{\prime} \mathrm{N} 39^{\circ} 22^{\prime} \mathrm{E}\right)$ & $\mathrm{W}$ & 2.4 & Silina, 2016 \\
\hline lakes $\left(47^{\circ} 45^{\prime} \mathrm{N} 9^{\circ} 01^{\prime} \mathrm{E}\right)$ & $\mathrm{W}$ & $1.6^{\mathrm{k}}$ & $\begin{array}{r}\text { Martin-Creuzburg et al., } 2017 \\
\text { Salvarina et al. } 2017\end{array}$ \\
\hline Average $\pm S E$ (standard error) & & $3.0 \pm 0.7$ & \\
\hline Coefficient of variation (\%) & & 23.3 & \\
\hline \multicolumn{4}{|c|}{ Temperate Grasslands, Savannas and Shrublands } \\
\hline wetland $\left(40^{\circ} \mathrm{N} 106^{\circ} \mathrm{W}\right)$ & $\mathrm{D}, \mathrm{Ch}$ & $1.2^{\mathrm{b}}$ & Whiles and Goldowitz, 2001 \\
\hline lakes \& wetlands $\left(54^{\circ} 35^{\prime} \mathrm{N} 78^{\circ} 10^{\prime} \mathrm{E}\right)$ & $\mathrm{O}$ & 0.9 & Gladyshev et al., 2011a \\
\hline 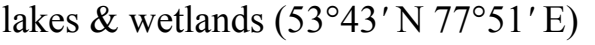 & $\mathrm{C}$ & 0.5 & Gladyshev et al., 2011b \\
\hline lakes $\left(51^{\circ} \mathrm{N} 46^{\circ} \mathrm{E}\right)$ & $\mathrm{W}$ & $0.2^{1}$ & Djomina et al., 2016 \\
\hline Average $\pm S E$ & & $0.7 \pm 0.2$ & \\
\hline Coefficient of variation (\%) & & 28.6 & \\
\hline \multicolumn{4}{|c|}{ Mediterranean Forests, Woodlands and Scrubs } \\
\hline $\operatorname{creek}\left(36^{\circ} 04^{\prime} \mathrm{N} 121^{\circ} 35^{\prime} \mathrm{W}\right)$ & $\mathrm{Ch}, \mathrm{E}, \mathrm{P}$ & $6.6^{\mathrm{b}}$ & Rundio and Lindley, 2012 \\
\hline \multicolumn{4}{|c|}{ Tropical and Subtropical Moist Broadleaf Forests } \\
\hline stream $\left(2^{\circ} \mathrm{S} 29^{\circ} \mathrm{E}\right)$ & $\mathrm{W}$ & $2.2^{\mathrm{m}}$ & Jackson and Fisher, 1986 \\
\hline rivers $\left(10^{\circ} \mathrm{N} 119^{\circ} \mathrm{E}\right)$ & $\mathrm{W}$ & $2.1^{\mathrm{h}}$ & Freitag, 2004 \\
\hline streams $\left(22^{\circ} 30^{\prime} \mathrm{N} 114^{\circ} \mathrm{E}\right)$ & $\mathrm{W}$ & 0.9 & Yuen and Dudgeon, 2016 \\
\hline river $\left(33^{\circ} \mathrm{S} 27^{\circ} \mathrm{E}\right)$ & $\mathrm{D}, \mathrm{E}, \mathrm{T}, \mathrm{O}$ & $101^{\mathrm{b}}$ & Moyo et al., 2017 \\
\hline Average $\pm S E$ & & $26.5 \pm 24.8$ & \\
\hline
\end{tabular}


Coefficient of variation (\%)

$\operatorname{creek}\left(33^{\circ} \mathrm{N} 111^{\circ} \mathrm{W}\right)$
93.6

Deserts and Xeric Shrublands

Ch, E, T

${ }^{a}$ recalculated using energy equivalent $1 \mathrm{~g} \mathrm{DM}=23 \mathrm{~kJ}$ (Alimov, 1989).

b average calculated from the authors' data.

caverage value calculated from Table 2 of the reference.

$\mathrm{d}$ average for two Austrian streams from Table 5 of the reference.

${ }^{\mathrm{e}}$ average for three German streams \& springs from Table 5 of the reference.

${ }^{\mathrm{f}}$ average for two Canadian rivers from Table 5 of the reference.

${ }^{\mathrm{g}}$ Sweden lake from Table 5 of the reference.

${ }^{\mathrm{h}}$ recalculated using an average specimen dry mass $150 \mu \mathrm{g}$ (Stagliano et al., 1998).

${ }^{\mathrm{i}}$ recalculated from Fig. $1 \mathrm{C}$ of the reference.

j recalculated from authors' data on secondary production in forested stream using their emergence/production ratio.

${ }^{\mathrm{k}}$ average value calculated for three lakes from data of the two papers.

${ }^{1}$ average value calculated from Table 3 of the reference.

$\mathrm{m}$ average for Zaire stream from Table 5 of the reference. 


\section{Table2}

Contents of the sum of eicosapentaenoic and docosahexaenoic fatty acids (EPA+DHA, $\mathrm{mg} \cdot \mathrm{g}^{-1}$ of dry mass) in the biomass of imago of emergent aquatic insects.

\begin{tabular}{lcrr}
\hline \multicolumn{1}{c}{ Taxa } & Water body & EPA+DHA & \multicolumn{2}{c}{ Reference } \\
\hline Chironomidae & The Yenisei River & 18.1 & Gladyshev et al., 2009 \\
Chironomidae & Lake Oiskoie & 11.9 & Borisova et al., 2016 \\
Chironomidae & Lake Mindelsee & $16^{1}$ & Martin-Creuzburg et al., 2017 \\
Chironomidae & Lake Shira & 10.1 & Makhutova et al., 2017 \\
Ephemeroptera & Lake Oiskoie & 11.3 & our data \\
Plecoptera & The Yenisei River \& Lake Oiskoie & 11.4 & our data \\
Trichoptera & The Yenisei River & 9.4 & our data \\
Odonata & Wetlands \& pools & 7.98 & Gladyshev et al., 2011a \\
Culicidae & Wetlands \& pools & $7.96^{2}$ & Gladyshev et al., 2011b \\
Chaoboridae & Lake Mindelsee & 33.7 & Martin-Creuzburg et al., 2017 \\
Miscellaneous & Lake Mindelsee & $13^{1}$ & Martin-Creuzburg et al., 2017 \\
\multicolumn{1}{c}{ Median } & & 11.4 & \\
\hline
\end{tabular}

${ }^{1}$ median value, approximated from Fig. 3 of the reference.

${ }^{2}$ calculated from Table 1 of the reference. 
Table 3

Ratio of water/land area for each biome (W/L), calculated from Table 3 of Feng et al., (2016), insect emergence to land area $\left(\mathrm{g} \mathrm{DM} \mathrm{m}^{-2}\right.$ year $\left.^{-1}\right)$ in the biomes and concomitant flux of the sum of eicosapentaenoic and docosahexaenoic fatty acids (EPA + DHA, $\mathrm{mg} \mathrm{m}^{-2}$ year $\left.^{-1}\right)$ : nd - no data.

\begin{tabular}{lrrr}
\hline \multicolumn{1}{c}{ Biome } & W/L & Emergence & EPA+DHA \\
\hline Tundra & 0.076 & 0.023 & 0.26 \\
Boreal Forests/Taiga & 0.057 & 0.086 & 0.98 \\
Temperate Broadleaf and Mixed Forests & 0.040 & 0.119 & 1.36 \\
Temperate Coniferous Forests & 0.016 & 0.003 & 0.04 \\
Temperate Grasslands, Savannas and Shrublands & 0.016 & 0.011 & 0.13 \\
Deserts and Xeric Shrublands & 0.006 & 0.130 & 1.48 \\
Montane Grasslands and Shrublands & 0.013 & nd & nd \\
Tropical and Subtropical Moist Broadleaf Forests & 0.015 & 0.385 & 4.39 \\
Tropical and Subtropical Coniferous Forests & 0.004 & nd & nd \\
Tropical and Subtropical Dry Broadleaf Forests & 0.013 & nd & nd \\
Tropical and Subtropical Grasslands, Savannas and Shrublands & 0.007 & nd & nd \\
Flooded Grasslands and Savannas & 0.050 & nd & nd \\
Mediterranean Forests, Woodlands and Scrubs & 0.008 & 0.052 & 0.60 \\
Mangroves & 0.098 & nd & nd \\
\hline
\end{tabular}

